\title{
Spatial structure of Punica granatum L. coenopopulations in the conditions of Northern Azerbaijan
}

\author{
Aydan M. Zeynalova \\ Institute of Botany, Azerbaijan National Academy of Sciences, \\ Badamdar 40, Baku, AZ1004, Azerbaijan
}

Abstract: The results of studying the spatial structure, ontogenetic state, morphometric and coenotic parameters of 14 coenopopulations of wild pomegranate growing in different regions of Azerbaijan are presented. Abiotic and biotic factors that could affect the variability of the phytocenotic composition, ontogenetic state, morphological parameters, and density of coenopopulations of this species were shown. Our studies showed that the studied coenopopulations belong to normal mature coenopopulations, where the individuals of the generative period constitute the maximum (51\%). The content of the postgenerative fraction is small (3.9$8 \%$ ). The ontogenetic spectra of CPs I, III, VII, VIII, XI and XIV are right-handed, CPs II, V, X, XII - bimodal, CPs IV, VI, IX, XIII - left-handed. Age $(\Delta)$ of the studied coenopopulations has a strong distribution amplitude from 0.22 (CP II) to 0.62 (CP XIV), efficiency indices range from 0.24 (CP II) to 0.67 (CP XIV). According to the "delta omega" criterion, three types of populations were obtained: young (CPs II, IV, V, VI, VII, IX, X, X, XII, XIII), transient (CPs I, III, VIII, XI) and aging (CP $\mathrm{XIV)}$. The value of the recovery index ranges from 0.14 (CP XIV) to 2 (CP VI). The most threatened state in CP $\mathrm{XIV}$, because of the population is aging and unstable. The density of individuals in the studied coenopopulations ranged from 0.3 to 0.5 individuals per $100 \mathrm{~m}^{2}$. The length of the petiole, the length and width of the leaf blade have low variation coefficients. The greatest amplitude of variation among morphological features of the species is linear dimensions of the plant height and leaf area.

Key Words: phytocenotic characteristic, ontogenetic state, morphometric and coenotic parameters

\section{INTRODUCTION}

Punica granatum L. from the Lythraceae family Jaume St.-Hil. is a fruit, medicinal, tannic and ornamental plant, widely distributed in the countries of the ancient Mediterranean. It is revealed that the native land of the

Accepted for publication: 15 November 2019

'E-mail: aydan.zeynalova.az@gmail.com wild pomegranate is the region covering the territories of the Caucasus, Iran and Northern India, and originates in the Middle East, Northern Iran, including Azerbaijan, in the whole of Southwest Asia [Zeynalova, Novruzov, 2017]. According to G.A. Nesterenko and A.R. Strebkova [1949], the homeland of pomegranate is Azerbaijan, Afghanistan, Balochistan, Iran. In these countries, the greatest diversity of varieties and pomegranates of wild forms is concentrated. The species is listed in the Red Book of Azerbaijan with the category vulnerable and status "VU" (in the IUCN Red List, the security status is "LC" (is under the least threat)) [Red Book of the Republic of Azerbaijan, 2013].

Recently, researchers have increased interest in studying the spatial structure of coenopopulations. The study of the spatial structure of coenopopulations makes it possible to imagine how the population size and age composition change over time, and also allows us to solve the problems of species relationships in the same cenosis and at the border of different phytocenoses [Tsenop. rast., 1977].

According to literature data, most of the research of pomegranate growing in Azerbaijan was carried out on the material of cultivated pomegranate and the data related to the biochemical composition of the plant [Garasharly, 1979; Sapozhnikova, 1940; Nesterenko, Strebkova, 1949; Aslanova, Maharramov, 2012]. The study of the biochemical composition and ways of using the fruits of wild pomegranate was done by E.V. Sapozhnikova, L.G. Gorponova [1954], A.D. Strelkova [1941], R.K. Aliyev [1949] and etc. The investigations of G.M. Levin [(Levin, 1981, 2007] is devoted to the study of Kopet-Dag wild-growing pomegranate, the studies of S.M. Gulov [1998] - to the timing of the passage of phenological phases of pomegranate in the Qussar valley, the researches of I.A. Boboev [ 2014] - to the study of pomegranate growing in the conditions of Tajikistan. However, in the literature there is no data on the study of the spatial structure of the cenopopulations of Punica granatum L., which grows in the territory of Azerbaijan. In this reason, the aim of this work is the first comprehensive work to establish the ranges of wild pomegranate distributed in Azerbaijan, the study of ontogenesis, as well as the variability of coenopopulations by morphometric and coenotic parameters. 


\section{MATERIAL AND METHODS}

Geobotanical research. The study of coenopopulations (CPs) of P. granatum was carried out in different districts of Azerbaijan: Khizi, Siyazan, Agsu, Agdash, Ismayilli, Yevlakh, Goychay, Sheki. The object of research was $P$. granatum, and the subject was cenopopulation of the plant. Geobotanical descriptions were carried out by generally accepted methods [Lemeza, Djus, 2008].

The study of coenopopulations was carried out using the trial plot method $(10 \mathrm{TP} ; 10 \times 10)$, where the area of coenopopulation $\left(\mathrm{m}^{2}\right)$, the absolute number of individuals (pcs.), and instance saturation (density) (pcs / $\mathrm{m}^{2}$ ) were studied. The density of coenopopulations in the case of large areas occupied by coenopopulations was estimated by the method of recounting individuals on trial plots (trial plot size $10 \times 10$ ). In this case, the number of plants in 10 such areas were calculated, after which the average value was estimated. For small areas, the method of direct recounting of all individuals within the population field was used [Metody izuch. tsenop. tsvetk. rast., 2015].

The names of associations (AS) were given by the number of species dominating in each tier, to which coenopopulation is confined [Shennikov, 1964]. The numbering of each association corresponded to the number of coenopopulation that was in it. The total projective cover (TPC) of the grass stand was determined by eye method.

The abundance was estimated on the Gult-Drude scale in order to identify the significance of the species in the community [Drude, 1913].

To determine the type of distribution of individuals of cenopopulations, a certain number of samples were taken and the number of individuals was calculated on equal areas and the variance $\left(\mathrm{S}^{2}\right)$ was determined [Izuc. popul. rast. naprom. otvalah, 2016]:

$$
\mathrm{S}^{2}=\frac{\Sigma(x-m)^{2}}{n-1}
$$

where $\mathrm{m}$-the average number of individuals on the site; $\mathrm{n}$ - the number of sites.

Ontogenetic investigation. An ontogenetic spectrum was constructed for all studied coenopopulations, which reflects the percentage ratio of individuals of all ontogenetic groups and indicates a certain stage in the development of coenopopulation [Uranov, Smirnova 1969; Zaugolnova, Smirnova, 1978; Zaugolnova, 1994]. Based on the analysis of ontogenetic spectrum, the type of studied coenopopulations was determined using the classification of L.A. Zhivotovsky [2001] and L.A. Zhukova and T.A. Polyanskaya [2013].

To assess the ontogenetic spectrum of coenopopulation, the age index proposed by A.A. Uranov [1975] was used. The age index $(\Delta)$ was determined by the following equation:

$$
\Delta=\frac{\Sigma k i \cdot m i}{\Sigma N}
$$

where $\mathrm{k}_{i}$ - number of individuals of $\mathrm{i}$ of ontogenetic structure in populations; $\mathrm{m}_{i}$-《value» of $i$ ontogenetic status; $\mathrm{N}$ - total number of individuals in population.

The efficiency index [Zhivotovsky, 2001] was considered as the energy load on the environment by different ontogenetic groups of plants and was determined by the equation below:

$$
\omega=\frac{\Sigma k i \cdot e i}{\Sigma N}
$$

where $\mathrm{k}_{i}$ - the absolute number of plants of $i$ age state; $\mathrm{e}_{i}-$ energy efficiency of plants of $i$ ontogenetic status in population; $\mathrm{N}-$ total number of individuals in population.

In addition, indicators such as recovery index $\left(\mathrm{I}_{\text {rec }}\right)$, replacement index $\left(\mathrm{I}_{\text {rep }}\right)$ and aging index $\left(\mathrm{I}_{\mathrm{a}}\right)$ were also determined.

$\mathrm{I}_{\mathrm{rec}}$ is the ratio of the number of individuals of the pregenerative period (seedlings are not taken into account) to the number of individuals of the generative period [Zhukova, 1987].

$$
\mathrm{I}_{\mathrm{rec}}=\frac{\Sigma j \rightarrow v}{\Sigma g 1 \rightarrow g 3}(3)
$$

where $\Sigma j \rightarrow v$ is the sum of plants of all age states of the pregenerative period, $\Sigma \mathrm{g} 1 \rightarrow \mathrm{g} 3$ is the sum of plants of all age states of the generative period.

$\mathrm{I}_{\mathrm{rep}}$ is the ratio of individuals of the pregenerative period (seedlings are not taken into account) to the sum of the numbers of individuals of the generative and postgenerative periods.

$$
\mathrm{I}_{\text {rep }}=\frac{\Sigma j \rightarrow v}{\Sigma g 1 \rightarrow s}
$$

where $\Sigma \mathrm{j} \rightarrow \mathrm{v}$ is the sum of plants of all ontogenetic states of the pregenerative period, $\Sigma \mathrm{g} 1 \rightarrow \mathrm{s}$ is the sum of plants of all ontogenetic states of the generative and postgenerative period [Zhukova, 1987].

$I_{a}$ is the ratio of the number of individuals of the postgenerative period to the number of all individuals 
of the population.

$$
\mathrm{I}_{\mathrm{a}}=\frac{\Sigma s s \rightarrow s}{\Sigma j \rightarrow g 3}
$$

where $\Sigma \mathrm{ss} \rightarrow \mathrm{s}$ is the sum of plants of all ontogenetic states of the postgenerative period, $\Sigma \mathrm{j} \rightarrow \mathrm{g} 3$ sum of plants of pregenerative and generative ontogenetic states [Qlotov, 1998].

Features of all ontogenetic states are described from natural populations.

Morphometric analysis. In population studies, it is necessary to study the morphological characteristics of plants. Qualitative and quantitative traits of individuals are useful in different ways. On the basis of qualitative characteristics the selection of the age-related states of plants and the analysis of the age spectra of populations are based. Quantitative indicators are more useful in the study of ontogenetic adaptations, in assessing the life state of individuals and in constructing the vitality spectra of populations [Zlobin, 1988]. Given the importance of morphometric studies in each TP, the height of the plant was recorded, annual shoots of $P$. granatum were taken to determine the statistical morphometric parameters of the leaves (area, length, width), as well as the leaf shape index (width / length). For this purpose, the parameters of indicator leaves were analyzed. Indicator leaves (the most sensitive to environmental factors) are the three most developed leaves on the shoot [Buzuk et al., 2006]. The area of the leaf blade was determined by the equation of I. Ju Bakkal [1990]:

$$
\mathrm{S}=\mathrm{a} x \mathrm{~L} x \mathrm{~W}
$$

where L, W - length and width of the leaf blade; a - calculated coefficient equal to 0.72 .

The Latin names of the plants have been determined according to "Flora of Azerbaijan" [Flora Azerbaidjana, 1952] and The Plant List.

Statistical Analysis. Statistical analysis of the research results was carried out in accordance with generally accepted methods using the computer program "MS Excel 2010". All data were expressed as means \pm SD.

\section{RESULTS AND DISCUSSION}

Plant associations. The CPs of wild-growing pomegranate, conditionally named by their location, were studied. Plant diversity within coenopopulations is the most important property of natural populations, which increases the completeness of resource use and their ability to adapt to the conditions of the plant community [Kudryavtsev, 2008]. Results on naming communities based on the dominant approach of V.V. Alekhine [1925] are shown in table 1.

The studied communities (CPs I - XIV) of $P$. granatum are characterized by a significant variety of meadow and forest meadow plants. In most of the studied cenoses, pomegranate is the dominant edificator (subviolent) with a projective cover of $60-90 \%$. Most often, representatives of the genus Tamarix L., as well as species of Rubus fruticosus L., Paliurus spina-christi Mill, etc., act as codominants. The results of assessing the abundance of herbaceous species in phytocoenoses are presented in table 2.

Phytocenotic characteristic of the habitat. CPs I-II are located in Siyazan district at an altitude of 230 and 250 $\mathrm{m}$ a. s. 1 . The soils in the region are predominantly saline soils [Azorbaycan: ekoturizm potensial1, 2012]. The grass of coenopopulation I is subject to annual mowing. Along with $P$. granatum, species of the genus Tamarix L., as well as Hypericum perforatum L., Trifolium pratense L., Paliurus spina-christi Mill., Bellis perennis L. are abundantly represented, less abundantly - Sorbus domestica L., Ranunculus repens L., Rhus coriaria L., Rosa canina L., Malus sylvestris (L.) Mill. The projective cover of $P$. granatum is $70-90 \%$.

CPs III-IV were found in Khizi district at an altitude of 200 and $250 \mathrm{~m}$ a. s. 1. The soils of the region are represented by gray-brown salt marshes [Azərbaycan: ekoturizm potensial1, 2012]. The soils of the region are represented by gray-brown salt marshes [Azərbaycan: ekoturizm potensial1, 2012]. Small abundance in these populations is typical for Eleagnus angustifolia L., Papaver rhoeas L., Carduus pycnocephalus L., Tragopogon dubius Scop. Projective covering of pomegranate is $50-70 \%$.

CPs V-VII are represented on the territory of Agsu district at the altitude of 420 (Aghu mountain pass), 200 (the right part of the Agsu bridge) and 190 (the left part of the Agsu bridge) m a. s. 1. The main soils of the region are salt marshes [Azərbaycan: ekoturizm potensial1, 2012].The following species can be found in the herbaceous-shrubby tier: Rubus fruticosus L., Malva sylvestris L., Hypericum perforatum L., Alhagi pseudoalhagi Bieb (Fisch.), Cirsium vulgare (Savi) Teh. In CP VII, Ficus carica L tree grow in a single specimen. Projective coating of pomegranate is 30 $40 \%$.

CPs VIII-IX are noted in the territories of Agdash (50 $\mathrm{m}$ a. s. 1.) and Yevlakh (60 m a. s. 1.) districts. The soils 


\section{PLANT \& FUNGAL RESEARCH}

Table 1. Characterization of associations with the participation of $P$. granatum.

\begin{tabular}{|c|c|c|c|c|}
\hline $\begin{array}{l}\text { Geographical } \\
\text { Position }\end{array}$ & $\begin{array}{c}\text { № CP } \\
\text { (GPS data) }\end{array}$ & $\begin{array}{l}\text { № } \\
\mathrm{AS}\end{array}$ & Name of AS & $\begin{array}{c}\text { TPC of } \\
\text { the grass, } \\
\%\end{array}$ \\
\hline \multirow{2}{*}{$\begin{array}{l}\text { Siyazan } \\
\text { district }\end{array}$} & $\begin{array}{c}\mathrm{I} \\
\left(49^{0} 01^{\prime} 04.752^{\prime \prime} \mathrm{E}-41^{0} 04^{\prime} 45.618^{\prime \prime} \mathrm{N}\right)\end{array}$ & 1 & $\begin{array}{l}\text { Punica granatum }+ \text { Tamarix spp.- Hypericum } \\
\text { perforatum }\end{array}$ & $60-80 \%$ \\
\hline & $\begin{array}{c}\text { II } \\
\left(49^{0} 00^{\prime} 14.454^{\prime \prime} \mathrm{E}-41^{0} 04^{\prime} 45.468^{\prime \prime} \mathrm{N}\right)\end{array}$ & 2 & Punica granatum-Trifolium pretense & $60-80 \%$ \\
\hline \multirow[b]{2}{*}{ Khizi district } & $\left(49^{0} 8^{\prime} 42.21^{\prime \prime} \mathrm{E}-40^{0} 54^{\prime} 15.56^{\prime \prime} \mathrm{N}\right)$ & 3 & Punica granatum + Tamarix spp. & $20-30 \%$ \\
\hline & $\begin{array}{c}\text { IV } \\
\left(49^{0} 11^{\prime} 18.73^{\prime \prime} \mathrm{E}-40^{0} 52^{\prime} 43.91^{\prime \prime} \mathrm{N}\right)\end{array}$ & 4 & Punica granatum - Crepis capillarys & $30-40 \%$ \\
\hline \multirow{3}{*}{ Agsu district } & $\begin{array}{c}\mathrm{V} \\
\left(48^{0} 25^{\prime} 24.33^{\prime \prime} \mathrm{E}-40^{0} 35^{\prime} 9.40^{\prime \prime} \mathrm{N}\right)\end{array}$ & 5 & $\begin{array}{l}\text { Punica granatum }+ \text { Rubus fruticosus }- \\
\text { Hypericum perforatum }\end{array}$ & $60-100 \%$ \\
\hline & $\begin{array}{c}\text { VI } \\
\left(48^{0} 23^{\prime} 51.97^{\prime \prime} \mathrm{E}-40^{0} 34^{\prime} 51.85^{\prime \prime} \mathrm{N}\right)\end{array}$ & 6 & $\begin{array}{l}\text { Punica granatum +Tamarix spp.- Cirsium } \\
\text { vulgare }\end{array}$ & $60-80 \%$ \\
\hline & $\begin{array}{c}\text { VII } \\
\left(48^{0} 23^{\prime} 51.50^{\prime \prime} \mathrm{E}-40^{0} 34^{\prime} 50.64^{\prime \prime} \mathrm{N}\right)\end{array}$ & 7 & $\begin{array}{l}\text { Punicagranatum + Tamarix spp.- Alhagi } \\
\text { pseudoalhagi }\end{array}$ & $40-50 \%$ \\
\hline $\begin{array}{c}\text { Agdash } \\
\text { district }\end{array}$ & $\begin{array}{c}\text { VIII } \\
\left(47^{0} 30^{\prime} 27.49^{\prime \prime} \mathrm{E}-40^{0} 38^{\prime} 43.81^{\prime \prime} \mathrm{N}\right)\end{array}$ & 8 & $\begin{array}{l}\text { Punica granatum }+ \text { Rubus fruticosus }- \text { Alhagi } \\
\text { pseudoalhagi }\end{array}$ & $30-40 \%$ \\
\hline $\begin{array}{c}\text { Yevlakh } \\
\text { district }\end{array}$ & $\begin{array}{c}\text { IX } \\
\left(47^{0} 12^{\prime} 14.81^{\prime \prime} \mathrm{E}-40^{\circ} 44^{\prime} 49.22^{\prime \prime} \mathrm{N}\right) \\
\end{array}$ & 9 & $\begin{array}{l}\text { Punica granatum }+ \text { Rubus fruticosus }- \text { Bellis } \\
\text { perennis }\end{array}$ & $30-40 \%$ \\
\hline $\begin{array}{l}\text { Goychay } \\
\text { district }\end{array}$ & $\begin{array}{c}\mathrm{X} \\
\left(48^{0} 0^{\prime} 48.23^{\prime \prime} \mathrm{E}-40^{0} 36^{\prime} 54.42^{\prime \prime} \mathrm{N}\right) \\
\end{array}$ & 10 & $\begin{array}{l}\text { Punica granatum }- \text { Trifolium pratense }+ \\
\text { Capsella bursa-pastoris }+ \text { Alhagi pseudoalhagi }\end{array}$ & $60-80 \%$ \\
\hline \multirow{2}{*}{$\begin{array}{l}\text { Ismailli } \\
\text { district }\end{array}$} & $\begin{array}{c}\text { XI } \\
\left(48^{0} 14^{\prime} 49.05^{\prime \prime} \mathrm{E}-40^{0} 37^{\prime} 29.06^{\prime \prime} \mathrm{N}\right)\end{array}$ & 11 & Punica granatum - Capsella bursa-pastoris & $80-100 \%$ \\
\hline & $\left(48^{0} 3^{\prime} 47.15^{\prime \prime} \mathrm{E}-40^{0} 45^{\prime} 2.82^{\prime \prime} \mathrm{N}\right)$ & 12 & $\begin{array}{l}\text { Punica granatum - Capsella bursa-pastoris } \\
\text { +Pimpinella peregrine }\end{array}$ & $80-100 \%$ \\
\hline \multirow{2}{*}{ Sheki district } & $\begin{array}{c}\text { XIII } \\
\left(47^{0} 7^{\prime} 31.20^{\prime \prime} \mathrm{E}-40^{0} 0^{\prime} 22.27^{\prime \prime} \mathrm{N}\right)\end{array}$ & 13 & $\begin{array}{l}\text { Punica granatum - Trifolium pratense + Crepis } \\
\text { capillaries }\end{array}$ & $80-90 \%$ \\
\hline & $\begin{array}{c}\text { XIV } \\
\left(47^{0} 11^{\prime} 29.33^{\prime \prime} \mathrm{E}-41^{0} 9^{\prime} 34.33^{\prime \prime} \mathrm{N}\right)\end{array}$ & 14 & $\begin{array}{l}\text { Punica granatum }- \text { Cirsium vulgare }+ \text { Capsella } \\
\text { bursa-pastoris }+ \text { Crepis capillaries }\end{array}$ & $80-90 \%$ \\
\hline
\end{tabular}

Table 2. Abundance of herbaceous species in associations.

\begin{tabular}{|c|c|c|c|c|c|c|c|c|c|c|c|c|c|c|}
\hline Plant species & \multicolumn{14}{|c|}{$\overline{\mathrm{ASS}}$} \\
\hline Hypericum perforatum L. & $\mathrm{cop}_{3}$ & $\mathrm{cop}_{2}$ & - & - & $\mathrm{cop}_{3}$ & $\mathrm{sp}$ & $\mathrm{sp}$ & $\mathrm{sp}$ & $\mathrm{sp}$ & - & $\mathrm{sp}$ & $\mathrm{sp}$ & $\mathrm{sp}$ & $\mathrm{sp}$ \\
\hline Bellis perennis L. & $\operatorname{cop}_{1}$ & $\operatorname{cop}_{1}$ & - & - & $\mathrm{sp}$ & - & - & - & $\mathrm{cop}_{3}$ & $\operatorname{cop}_{1}$ & $\mathrm{sp}$ & $\mathrm{sp}$ & $\operatorname{cop}_{1}$ & $\mathrm{sp}$ \\
\hline Capparis spinosa $\mathrm{L}$. & - & - & $\mathrm{sp}$ & $\operatorname{cop}_{1}$ & - & - & - & - & - & - & - & - & - & - \\
\hline Taraxacum officinale F.H. Wigg & - & - & $\mathrm{sp}$ & $\mathrm{sp}$ & $\mathrm{sp}$ & $\operatorname{cop}_{1}$ & $\mathrm{sp}$ & $\operatorname{cop}_{1}$ & $\operatorname{cop}_{1}$ & $\operatorname{cop}_{2}$ & $\operatorname{cop}_{2}$ & $\operatorname{cop}_{2}$ & $\operatorname{cop}_{1}$ & $\operatorname{cop}_{1}$ \\
\hline Crepis capillary (L.) Wallr. & $\mathrm{sp}$ & $\mathrm{sp}$ & $\mathrm{sp}$ & $\mathrm{cop}_{3}$ & - & - & - & - & $\mathrm{cop}_{2}$ & - & - & - & $\mathrm{cop}_{3}$ & $\operatorname{cop}_{3}$ \\
\hline Malva sylvestris L. & - & - & - & - & soc & $\operatorname{cop}_{1}$ & $\mathrm{sp}$ & - & - & - & - & - & - & - \\
\hline Capsella bursa-pastoris (L.) Medik & $\mathrm{sp}$ & $\mathrm{sp}$ & $\mathrm{sp}$ & $\mathrm{sp}$ & soc & $\operatorname{cop}_{1}$ & $\operatorname{cop}_{1}$ & $\operatorname{cop}_{1}$ & $\mathrm{cop}_{2}$ & $\mathrm{cop}_{3}$ & $\mathrm{cop}_{3}$ & $\operatorname{cop}_{2}$ & $\operatorname{cop}_{1}$ & $\mathrm{cop}_{3}$ \\
\hline Alhagi pseudoalhagi Bieb (Fisch.) & sol & sol & $\mathrm{sp}$ & $\mathrm{sp}$ & $\operatorname{cop}_{1}$ & $\operatorname{cop}_{1}$ & $\mathrm{cop}_{3}$ & $\mathrm{cop}_{3}$ & $\mathrm{sp}$ & $\mathrm{cop}_{3}$ & $\mathrm{sp}$ & $\mathrm{sp}$ & $\mathrm{sp}$ & $\mathrm{sp}$ \\
\hline Pimpinella peregrine $\mathrm{L}$. & - & - & - & - & - & - & - & - & - & - & $\mathrm{sp}$ & $\operatorname{cop}_{3}$ & - & - \\
\hline Papaver rhoes L. & $\mathrm{sp}$ & $\mathrm{sp}$ & $\operatorname{cop}_{1}$ & $\operatorname{cop}_{1}$ & $\mathrm{sp}$ & $\mathrm{sp}$ & $\mathrm{sp}$ & - & $\mathrm{sp}$ & $\mathrm{sp}$ & $\mathrm{sp}$ & $\operatorname{cop}_{1}$ & $\operatorname{cop}_{1}$ & $\operatorname{cop}_{1}$ \\
\hline Ranunculus repens L. & sol & - & - & - & - & - & - & - & - & - & sol & sol & - & - \\
\hline
\end{tabular}

Note: soc - all over the place, $\operatorname{cop}_{3}$ - very abundant, $\operatorname{cop}_{2}$ - abundant, cop 1 - quite abundant, sp - diffusely, sol - isolated, un - a single copy. 
of the regions are saline earth serozems [Azərbaycan: ekoturizm potensial1, 2012].CP VIII is characterized by the lowest value of the projective cover of $P$. granatum $(10-15 \%)$ and poor species diversity, consisting of the following species: Rubus fruticosus L., Capparis spinosa L., Alhagi pseudoalhagi Bieb (Fisch.) and various weeds. Projective pomegranate coating in $\mathrm{CP}$ IX is $70-80 \%$.

CPs X-XII have been studied in Goychay (CP X, $170 \mathrm{~m}$ a. s. 1.) and Ismailli (CP XI, $280 \mathrm{~m}$ a. s. 1.; CP XII, $540 \mathrm{~m}$ a. s. 1.) districts. The cha-racteristic soils of the Goychay region are light brown soils, and those of the Ismayilli region are mountain-brown soils [Azərbaycan: ekoturizm potensial1, 2012]. Plants of $P$. granatum from CP XI are distinguished by the highest height of shoots (up to $8 \mathrm{~m}$ ). The following species dominate in the herbaceous tier of the studied populations: Capsella bursapastoris (L.) Medik, Alhagi pseudoalhagi Bieb (Fisch.), Paliurus spina-christi Mill. Projective pomegranate coverage in these populations is $60-80 \%$.

CPs XIII - XIV were studied in Sheki region at an altitude of 340 and $380 \mathrm{~m}$ a. s. 1. The main soils are light chestnut and chestnut [Azərbaycan: ekoturizm potensial1, 2012]. In the grassy tier are dominated, Paliurus spina-christi Mill., Trifolium pratense L., Crepis capillaries (L.) Wallr. The projective coverage of pomegranate in these coenopopulations is $50-80 \%$.

Main types of climateof regions are following: Climate of semi-deserts and dry steppes üith mild winter and dry hot summer (Siyazan, Agsu, Agdash, Yevlakh), temperatly warm climate with dry winter (Khizi, Goychay, Ismayilli), temperally warm climate with even distribution of precipitation (Sheki) [Azərbaycan Respublikasi: ekoloji atlas, 2009].

The type of distribution of individuals in CPs I-IV, VIII-IX, XIII-XIV is group, CPs V-VII - random-clinial and contagious-clinial and CPs X-XII - evenly. As can be seen from theobtaineddata, the predominant type of distribution of individuals is group. According to Yu.V. Ibatulina [2007], under the condition of intensive anthropogenic impact on the vegetation cover, the group distribution of individuals of coenopopulations of one or another spesies is often preserved, which is observed in CPs I - IV, XIII - XIV. For coenopopulations of edificator species, if one of them experiences competitive pressure from the other dominant species, but is stable in the community, contagious distribution of individuals is typical [Zaugolnova, 1976]. It is believed that the random (uniform) distribution of the species over the area indicates its prosperity, the approximation of the growing conditions to its ecological norm, and its stable position in the phytocenosis [Ibatulina, 2007].

As a life form of a pomegranate, it is usually indicated that it is a tree or shrub. It should be noted that the life form of the tree in pomegranate is the result of forming and is observed only in culture. The life form of wild pomegranate is a geoxyl bush.

The density of individuals in the studied coenopopulations ranged from 0.40 to 0.88 individuals per $100 \mathrm{~m}^{2}$. Morphometric analysis. In coenopopulation studies, the use of morphometric methods makes it possible to give a quantitative assessment of the morphological status, growth and production processes of plants, to assess the interrelation of individual parameters of the morphological structure of plants and, on this basis, to characterize the level of integrity of individuals, to obtain information for the subsequent identification of key, indicator morphological parameters, on the basis of which a comprehensive assessment and diagnosis of the vital state of individuals of plants is possible [Metody izuch..., 2015]. Morphometric parameters of individuals are given in table 3 which shows that the plant height and leaf area are highly variable. The length of the petiole, the length and width of the leaf blade have low variation coefficients. Plants from CPs XI, XIII have the highest height $(6.33 \pm 0.9 ; 6 \pm 0.66 \mathrm{~m})$, and from CPs III and VIII - the largest area of the leaf blade $(10.07 \pm 0.27)$.

The smallest length is characteristic for specimens of CP IX $(3.40 \pm 0.5 \mathrm{~cm})$, and the smallest width of the leaf blade is characteristic for plants of CP XIV $(1.25 \pm 0.14$ $\mathrm{cm})$. The length of the leaf petiole in plants from CP X is much higher than in other samples $(2.00 \pm 0.21 \mathrm{~cm})$. Morphological measurements of fruits were represented in a previous research [Zeynalova et al., 2019].

Ontogenetic analysis. The obtained biometric values of pomegranate allow us to introduce another quantitative characteristic of the degree of development of the individual. Studies of the age state of pomegranate specimens revealed the following states: juvenile (j), immature (im), virgin (v), generative (g1, g2, g3), and post-generative (ss, s).

The ontogenetic structure of coenopopulations of $P$. granatum, growing on the territory of the Great Caucasus (within Azerbaijan), has not been studied yet. According to the classification of L.A. Zhivotovsky [2001] studied coenopopulations belong to normal mature coenopopulations, where the maximum falls on individuals of the generative period (5-51\%). The content of the postgenerative fraction is small - 3.9-8\% (Fig.). 


\section{PLANT \& FUNGAL RESEARCH}

Table 3. Statistical morphometric parameters of the studied pomegranate bushes.

\begin{tabular}{|c|c|c|c|c|c|c|c|c|c|c|c|c|c|c|}
\hline \multirow{2}{*}{ № CPs } & \multicolumn{14}{|c|}{ CPs } \\
\hline & I & II & III & IV & V & VI & VII & VIII & IX & $X$ & XI & XII & XIII & XIV \\
\hline \multirow{2}{*}{$\mathrm{H}$} & $4.9 \pm$ & $3.9 \pm$ & $3.7 \pm$ & $4.37 \pm$ & $4.16 \pm$ & $4.23 \pm$ & $3.33 \pm$ & $4.66 \pm$ & $4.57 \pm$ & $4.23 \pm$ & $6.33 \pm$ & $3.77 \pm$ & $6 \pm$ & $4.1 \pm$ \\
\hline & 0.66 & 0.54 & 0.2 & 0.51 & 0.58 & 0.51 & 0.48 & 0.55 & 0.63 & 0.51 & 0.9 & 0.18 & 0.66 & 0.6 \\
\hline \multirow{2}{*}{$\mathrm{L}_{\text {fol }}$} & $5.09 \pm$ & $4.87 \pm$ & $5.05 \pm$ & $4.90 \pm$ & $4.87 \pm$ & $5.32 \pm$ & $5.41 \pm$ & $6.39 \pm$ & $3.40 \pm$ & $4.70 \pm$ & $5.11 \pm$ & $4.80 \pm$ & $5.37 \pm$ & $5.41 \pm$ \\
\hline & 0.31 & 0.72 & 0.74 & 0.68 & 0.35 & 0.74 & 0.43 & 0.9 & 0.5 & 0.7 & 0.66 & 0.70 & 0.72 & 0.31 \\
\hline \multirow{2}{*}{$\mathrm{Wh}_{\mathrm{fol}}$} & $1.74 \pm$ & $2.10 \pm$ & $2.77 \pm$ & $1.97 \pm$ & $1.38 \pm$ & $1.76 \pm$ & $1.67 \pm$ & $1.93 \pm$ & $1.42 \pm$ & $1.42 \pm$ & $2.17 \pm$ & $1.89 \pm$ & $1.36 \pm$ & $1.25 \pm$ \\
\hline & 0.2 & 0.31 & 0.4 & 0.29 & 0.11 & 0.25 & 0.09 & 0.05 & 0.21 & 0.03 & 0.27 & 0.23 & 0.16 & 0.14 \\
\hline \multirow[b]{2}{*}{$\mathrm{S}_{\mathrm{fol}}$} & $6.38 \pm$ & $7.36 \pm$ & $10.07 \pm$ & $6.95 \pm$ & $4.84 \pm$ & $6.74 \pm$ & $6.5 \pm$ & $8.88 \pm$ & $3.48 \pm$ & $4.81 \pm$ & $7.98 \pm$ & $6.53 \pm$ & $5.26 \pm$ & $4.87 \pm$ \\
\hline & 0.31 & 0.44 & 0.27 & 0.59 & 0.07 & 0.15 & 0.13 & 0.09 & 0.05 & 0.23 & 0.67 & 0.74 & 0.14 & 0.22 \\
\hline \multirow{2}{*}{$\mathrm{L}_{\mathrm{fol}} / \mathrm{Wh}_{\mathrm{fol}}$} & $2.93 \pm$ & $2.32 \pm$ & $1.82 \pm$ & $2.49 \pm$ & $3.53 \pm$ & $3.02 \pm$ & $3.23 \pm$ & $3.31 \pm$ & $2.39 \pm$ & $3.30 \pm$ & $2.35 \pm$ & $2.54 \pm$ & $3.94 \pm$ & $4.33 \pm$ \\
\hline & 0.16 & 0.09 & 0.23 & 0.33 & 0.41 & 0.06 & 0.29 & 0.37 & 0.24 & 0.08 & 0.03 & 0 & 0.37 & 0.05 \\
\hline \multirow{2}{*}{$\mathrm{L}_{\text {pet }}$} & $0.48 \pm$ & $0.51 \pm$ & $0.33 \pm$ & $0.25 \pm$ & $0.32 \pm$ & $0.41 \pm$ & $0.45 \pm$ & $0.47 \pm$ & $0.41 \pm$ & $2.00 \pm$ & $0.49 \pm$ & $0.42 \pm$ & $0.33 \pm$ & $0.32 \pm$ \\
\hline & 0.05 & 0.06 & 0.3 & 0 & 0.02 & 0.04 & 0.01 & 0.06 & 0.02 & 0.21 & 0.06 & 0.04 & 0.01 & 0.01 \\
\hline
\end{tabular}

Note: $H$ - plant height, $L_{\text {fol }}$ - leaf blade length, $W h_{f o l}$-leaf blade width, $S_{\text {fol }}$-leaf blade area, $L_{\text {pet }}$ - petiole length.

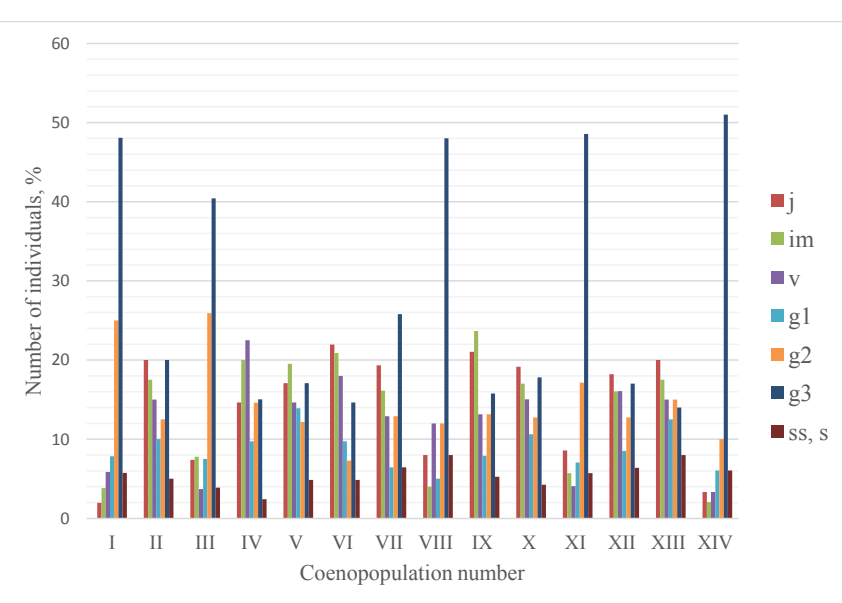

Figure. Ontogenetic spectrums of $P$. granatum populations.
The ontogenetic spectrums of CPs I, III, VII, VIII, $\mathrm{XI}$ and XIV are right-handed (with an absolute maximum on old generative individuals), CPs II, V, X, XII - bimodal (with a maximum in the virgin and generative parts, respectively), CPs IV, VI, IX, XIII - left-handed (with an absolute maximum for young individuals). A high percentage of middle-aged generative plants in the examined coenopopulations, and on the other hand, is determined by the elimination of young fractions as a result of various factors, and on the other, with a gradual increase in the life expectancy of individuals in the generative period.

The minimum proportion of individuals on the right side of the spectrum in most cases is associated with frequent death of individuals in the postgenerative period. All studied populations are full-term and are in a definitive state.

Table 4. Some demographic indicators of P. granatum coenopopulations.

\begin{tabular}{|c|c|c|c|c|c|c|c|c|c|c|c|c|c|c|}
\hline \multirow[t]{2}{*}{ № CP } & \multicolumn{14}{|c|}{ Ceonopopulations } \\
\hline & I & II & III & IV & V & VI & VII & VIII & IX & $\mathrm{X}$ & XI & XII & XIII & XIV \\
\hline $\mathrm{I}_{\mathrm{rec}}$ & 0.35 & 1.23 & 0.24 & 1.35 & 1.16 & 2 & 1.07 & 0.35 & 1.57 & 1.25 & 0.29 & 1.44 & 1.24 & 0.14 \\
\hline $\mathrm{I}_{\text {rep }}$ & 0.32 & 1.10 & 0.26 & 1.35 & 1.05 & 1.73 & 0.93 & 0.31 & 1.38 & 1.13 & 0.27 & 1.44 & 1.16 & 0.17 \\
\hline $\mathrm{I}_{\mathrm{a}}$ & 0.1 & 0.08 & 0.07 & 0.03 & 0.07 & 0.01 & 0.08 & 0.06 & 0.02 & 0.07 & 0.12 & 0.04 & 0.05 & 0.15 \\
\hline$\Delta$ & 0.43 & 0.22 & 0.37 & 0.30 & 0.30 & 0.26 & 0.25 & 0.36 & 0.32 & 0.31 & 0.36 & 0.30 & 0.27 & 0.62 \\
\hline$\omega$ & 0.46 & 0.24 & 0.41 & 0.33 & 0.32 & 0.30 & 0.28 & 0.43 & 0.35 & 0.34 & 0.42 & 0.33 & 0.31 & 0.67 \\
\hline $\begin{array}{l}\text { Type of CP by } \\
\text { criterion of } \\
\text { "delta-omega" }\end{array}$ & $\mathrm{T}$ & $\mathrm{Y}$ & $\mathrm{T}$ & $\mathrm{Y}$ & $\mathrm{Y}$ & $\mathrm{Y}$ & $\mathrm{Y}$ & $\mathrm{T}$ & $\mathrm{Y}$ & $\mathrm{Y}$ & $\mathrm{T}$ & $\mathrm{Y}$ & $\mathrm{Y}$ & A \\
\hline Type of CP by $\mathrm{I}_{\mathrm{rep}}$ & U & $\mathrm{P}$ & U & $\mathrm{P}$ & $\mathrm{P}$ & $\mathrm{P}$ & U & U & $\mathrm{P}$ & $\mathrm{P}$ & U & $\mathrm{P}$ & $\mathrm{P}$ & U \\
\hline
\end{tabular}

Note: $T$-transition, $Y$-young, $A$-aging, $P$-perspective, $U$-unstable. 
Thus, the CPs of wild pomegranate, represented by the majority of ontogenetic states, prevails, which indicates the stability and ability of the CPs to maintain themselves.

In order to assign $P$. granatum populations to a certain class, we calculated $\Delta, \omega, \mathrm{I}_{\text {rep }}, \mathrm{I}_{\mathrm{a}}$, and $\mathrm{I}_{\text {rec }}$ (Table 4).

Age $(\Delta)$ of the studied coenopopulations has a strong distribution amplitude from 0.22 (CP II) to 0.62 (CP $\mathrm{XIV}$ ), efficiency indices range from 0.24 (CP II) to 0.67 (CP XIV). Three types of populations were obtained by the using the "delta omega" [Zhivotovskij, 2001] criterion: young (CPs II, IV, V, VI, VII, IX, X, X, XII, XIII), transient (CPs I, III, VIII, XI), aging (CP XIV). The recovery index determined by the content of the young ontogenetic part of the population ranges from 0.14 (CP XIV) to 2 (CP VI). The table shows that the most threatened state in CP XIV in which the population is aging and unstable. The minimum share of the pregenerative fraction in this assessment population can be conditioned by the following factors: the death of immature individuals occurs as a result of grazing and trampling of vegetation by cattle, which cause a decrease in productivity and the effectiveness of seed and vegetative propagation; soil and climatic conditions and interpopulation relations hinder the increase of the number of young individuals in this $\mathrm{CP}$ of pomegranate.

\section{CONCLUSION}

The ceonopopulations of $P$. granatum, which are spread in various districts of Azerbaijan, are characterized by a significant variety of meadow and forest-meadow plants. In all studied cenoses, pomegranate is most often the dominant. The greatest amplitude of variation among the morphological characters of the species is the linear size of the shoot height and the area of the leaf blade. The age structure of the Punica granatum coenopopulations in different localities of Azerbaijan is heterogeneous, due to the dependence on a specific ecological and phytocenotic situation. An analysis of morphometric parameters, phytocenotic composition, ontogenetic state, and density of coenopopulations of the studied species suggests that abiotic and biotic factors could influence the variability of these parameters. Among the abiotic factors, the main ones were: the influence of soil and climatic factors and the height of growth. Among biotic factors - the duration of passage of age-related conditions; lower mortality of individuals of high vitality; accelerating the pace of development and reducing the time spent in the corresponding age states, grazing and trampling of young individuas by cattle, which cause a decrease in productivity, the effectiveness of seed and vegetative propagation.

\section{REFERENCES}

Alekhin V.V. (1925) Fitosociologiya (uchenie o rastitel'nyh soobshchestvah) i ee poslednie uspekhi $\mathrm{u}$ nas i na zapade. Metodika geobotanicheskih issledovanij. L.: Puchina, 130 p.

Aliev R.K. (1949) Ispol'zovanieplodovdikogogranatad ljapoluchenijamedicinskojlimonnojkisloty i limonnogonatra. Doklad AN AzSSR, 9: 16-18. (In Russian)

Aslanova M.S., Magerramov M.A. (2012) Fiziko-himicheskie pokazateli i aminokislotnyj sostav novyh pomologicheskih sortov plodov granata. Himija rastitel'nogo syr'ja. 1: 165-169. (In Russian)

Azorbaycan Respublikası: ekoloji atlas (2009) Bak1 Kartoqrafiya Fabriki. Bak1, 156 p. (In Azerbaijani)

Azərbaycan: ekoturizm potensialı (2012) Ed.: Məmmədov Q., Yusifov E., Xəlilov M., Kərimov V.,. Bak1: Qərb-Şərq, I cild: 360 p. (In Azerbaijani)

Azərbaycan: ekoturizm potensial1 (2012) Ed.: Məmmədov Q., Yusifov E., Xəlilov M., Kərimov V., Bak1: Qərb-Şərq, II cild: 420 p. (In Azerbaijani)

Bakkal I.Ju., Ljanguzova I.V., Tihmeneva I.B. (1990) Sostojanie assimiljacionnogo apparata kustarnichkov. Vlijanie promyshlennogo atmosfernogo zagrjaznenija na sosnovye lesa Kol'skogo poluostrova. L: izd-vo AN SSR, pp. 112-116. (In Russian)

Buzuk G.N. Morfometrija lekarstvennyh rastenij. (2006) 1. Vaccinium vitis-idaea L. Izmenchivost' formy i razmerov list'ev. Vestn.farmacii. 2: 21-33. (In Russian)

Drude O. (1913) Die Ökologie der Pflancen. - Brauncshweig.

Flora Azerbaidjana (1952) Ed.: D.I. Sosnovski, I.I. Karyaqin. Baku: AN Azerb. SSR, 6: 540 p. (In Russian)

Glotov N.V. (1998) Ob ocenke parametrov vozrastnoj struktury populjacij rastenij. Zhizn' populjacij v geterogennoj srede. Joshkar-Ola: MarGu, pp. 146-149. (In Russian)

Ibatulina Ju.V. (2007) Prostranstvennaja struktura cenopopuljacij stepnyh edifikatorov na jugo-vostoke Ukrainy. Promysh. botanika, 7: 73-79. (In Russian)

Izuchenie populjacij rastenij na promyshlennyh otvalah (2016) I395 [ucheb. posobie]/[M.A. Glazyrina, E.I. Filimonova, N.V. Lukinai dr.] M-voobrazovanija I naukiRos. Federacii, Ural. feder. un-t. Ekaterinburg: Izd-vo Ural. un-ta, 228 p. (In Russian)

Kudrjavcev A.Ju. (2008) Dinamika cenopopuljacij 


\section{PLANT \& FUNGAL RESEARCH}

derev'ev i kustarnikov lesostepnogo kompleksa privolzhskoj vozvyshennosti. Povolzh. ekol. zhurnal, 1: 29-38. (In Russian)

Qarasharly A.S. (1979) Granati ego ispol'zovanija. Baku, Azerneshr. 119 p. (In Russian)

Lemeza N.A., Djus M.A. (2008) Geobotanika: Ucebnaja praktika, Minsk, 225 p. (In Russian)

Levin G.M. (1981) Dikij granat (Punica granatum L.) v Turkmenistane. Izv. AN Turkm. SSR. 2: 60-64. (In Russian)

Levin G.M. (2007) Punica granatum (Punicaceae): biologija, jekologija i geografija vida. Bot. zhurn., 92(2): 185-211. (In Russian)

Metody izuchenija tsenopopuljacij tsvetkovyh rastenij (2015). Uchebno-metodicheskoe posobie dlja magistrov biologicheskogo fakul'teta./Sost. A.S. Kashin, T.A. Krickaja, N.A. Petrova, I.V. Shilova. Saratov, 127 p. (In Russian)

Nesterenko G.A., Strebkovoj A.D. (1949) Granat. Baku: «Sel'shozgiz». 56 p. (In Russian)

Red book of Azerbaijan (2013) Rare and endangered plant and fungi species. Second edition., Baku, 676 p. (In Azerbaijani)

Sapozhnikova E.V. (1940) Biohimija granata. Sb. biohimija kul'turnyh rastenij. 7: 90-95. (In Russian)

Sapozhnikova E.V., Gorponova L.G. (1954) Kompleksnoe ispol'zovanie dikogo granata. Sb. NI rabot AzNII mnogoletnih nasazhdenij, 2: 33-34. (In Russian)

Strelkova A.D. (1941) Ispol'zovanie dikih granatov i inzhirov v Azerbajdzhane. Bjulleten' VNIISS, 2: 2630. (In Russian)

Shennikov A.P. (1967) Vvedenie v geobotaniku. L.: izd-vo LGU, 447 p. (In Russian)

The Plant List: http://www.theplantlist.org/tpl1.1/record/ kew-2748734

Tsenopopuljacii rastenij (razvitie i vzaimootnoshenija). - M.: Nauka, 1977., 183 p. (In Russian)

Uranov A.A. (1975) Vozrastnoj spektr fitocenopopuljacij kak funkcija vremeni i jenergeticheskih volnovyh processov. Biol. nauki, 2: 7-34. (In Russian)

Zaugol'nova L.B. (1976) Neodnorodnost' stroenija cenopopuljacij vo vremeni i prostranstve (na primere Alyssum lenense Adams.) Botan. zhurn., 61(2): 187-196, (In Russian)

Zaugol'nova L.B. (1993) Podhody k ocenke sostojanija cenopopuljacij rastenij. L.B. Zaugol'nova, L.V. Denisova, S.V. Nikitina. Bjul. MOIP. Otd. biol. 98 (5): 100-108. (In Russian)

Zaugol'nova L.B. (1994) Struktura populjacij semennyh rastenij i problemy ih monitoringa: Avtoref. diss. dok. biol. nauk. SPb, 70 p. (In Russian)
Zaugol'nova L.B., Smirnova O.V. (1978) Vozrastnaja struktura cenopopuljacij mnogoletnih rastenij i ejo dinamika. Zhurn. obshh. biologii. 39(6): 849-857. (In Russian)

Zeynalova A.M., Novruzov E.N. (2017) Origin, taxonomy and systematic of pomegranate. Proceedings of the Institute of Botany, ANAS. Baku, 14: 20-25.

Zeynalova A.M., Novruzov E.N., Maserti B. (2019) Studies on the Physico-Chemical Characteristics, Antioxidant Activity and juice organic compound composition in Azerbaijan Wild Pomegranate Fruits. Plant \& Fungal Research, 2: 40-46.

Zhivotovskij L.A. (2001) Ontogeneticheskie spektry, jeffektivnaja plotnost' i klassifikacija populjacij rastenij. J. Ekologija, 1: 3-7. (In Russian)

Zhukova L.A. (1987) Dinamika cenopopuljacij lugovyh rastenij. Dinamika cenopopuljacij travjanistyh rastenij. Kiev: Naukovadumka. pp. 9-19. (In Russian)

Zhukova L.A., Poljanskaja T.A. (2013) O nekotoryh podhodah $\mathrm{k}$ prognazirovaniju perspektiv razvitija cenopopuljacij rastenij. Vestnik TvGU. Serija "Biologija i ekologija”, 32(31): 160-171. (In Russian)

Zlobin Ju. A. (1988) Principy i metody izuchenija cenoticheskih populjacij rastenij (ocherki populjacionnoj biologii). M., 184 p. (In Russian)

\section{Şimali Azərvaycan şəraitində Punica granatum L. senopopulyasiyalarının məkan quruluşu}

\section{Aydan M. Zeynalova}

AMEA Botanika İnstitutu, Badamdar şossesi 40, Bakl, AZ1004, Azərbaycan

Məqalədə Azərbaycanın müxtəlif rayonlarında bitən adi nar növünün 14 senopopulyasiyasının məkan quruluşu, ontogenetik vəziyyəti, morfometrik ve senotik göstəricilərinin öyrənilməsinin nəticələri verilir. Senopopulyasiyanın sıxlığının dəyişməsinə, dayanıqlı̆̆1 prosesinə, fitosenoloji tərkibinə, ontogenetik vəziyyətinə, və morfometrik ölçülərinətəsir edə biləcək abiotik və biotik amillər göstərilmişdir. Tədqiqat göstərir ki, öyrənilən populyasiyalar normal yetkin senopopulyasiyalara aiddir. Beləki, fərdlərin maksimum miqdarı (51\%) generativ, az hissəsi (3.9$8 \%$ ) postgenerativ dövrdədir. I, IV, V, VI, VII, IX, X, XII, XIII senopopulyasiyaların baza spektrı sağ yönümlü, SP II, V, X, XII - bimodal və SP IV, VI, IX, XIII - sol yönümlüdir. Öyrənilən senopopulyasiyaların yaş vahidi $(\Delta)$ geniş paylanma amplitudasına 0.22 (SP II) - 0.62 (SP XIV) arasında dəyişir. "Delta-omega" qiymətləndirməsindən istifadə etdikdə 3 tip senopopu- 
lyasiya: cavan (II, IV, V, VI, VII, IX, X, XII, XIII), keçid (SP I, III, VIII, XI) və yaşlı (SP XIV) aşkar edilmişdir. Senopopulyasiyaların bərpa olunma indeksi 0.14 (SP XIV)-2.0 (SP VI) arasında dəyişir. Müəyyən edilmişdir ki, SP XIV yaşlı və qeyri-sabit fərdlərdən təşkil olunub, təhlükə həddindədir. Tədqiq olunan senopopulyasiyalardaki fərdlərin sıxlığ $100 \mathrm{~m}^{2}$ sahədə 0.3-0.5 arasında dəyişilir. Saplağın uzunluğu, yarpaq ayasının uzunluğu və eni aşağı variasiya əmsalı göstəricisinə malikdirlər. Növün morfoloji əlamətləri arasında kolun hündürlüyü və yarpaq ayasının ölçüləri daha çox amplituda dəyişkənliyilə fərglənir.

Açar sözlor: fitosenotik xüsusiyyat, ontogenetik vaziyyat, morfometrik va senotik göstaricilar

\section{Пространственная структура ценопопуляций Punica granatum L. в условиях Северного Азербайджана}

\section{Айдан М. Зейналова \\ Институт Ботаники НАНА, Бадамдар 40, Баку, АZ1004,Азербайджан}

Представлены результаты изучения пространственной структуры, онтогенетического состояния, морфометрических и ценотических параметров 14 ценопопуляций дикого граната, произрастающих в различных районах Азербайджане. Были показаны абиотические и биотические факторы, которые могли влиять на изменчивость фитоценотического состава, онтогенетического состояния, морфологиче- ских параметров и плотности ценопопуляций этого вида. Наши исследования показали, что изученные ценопопуляции относятся к нормальным зрелым ценопопуляциям, где преобладают особи генеративного периода (51\%). Содержание постгенеративной фракции невелико (3.9-8\%). Онтогенетические спектры ЦП I, III, VII, VIII, XI и XIV - правосторонние, ЦП II, V, X, XII - бимодальные, ЦП IV, VI, IX, XIII - левосторонние. Возраст $(\Delta)$, исследованных ценопопуляций имеет сильную амплитуду распределения от 0.22 (ЦП II) до 0.62 (ЦП XIV), показатели эффективности колеблются от 0.24 (ЦП II) до 0.67 (ЦП XIV). По критерию «дельта-омега» было получено три типа популяций: молодые (ЦП II, IV, V, VI, VII, IX, X, X, XII, XIII), переходные (ЦП I, III, VIII, XI) и старые (ЦП XIV). Значение индекса восстановления варьируется от 0.14 (ЦП XIV) до 2 (ЦП VI). Наиболее угрожаемоесостояниеу ЦП XIV, популяция является стареющей и неустойчивой. Плотность особей в исследованных ценопопуляци-

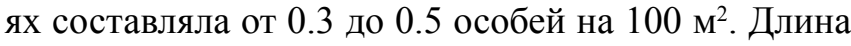
черешка, длина и ширина листовой пластинки имеют низкие коэффициенты вариации. Наибольшей амплитудой вариации среди морфологических признаков характеризуются линейные размеры высоты побега и площади листьев.

Ключевые слова: фиточенотическая характеристика, онтогенетическое состояние, морфометрические и иенотические параметры 